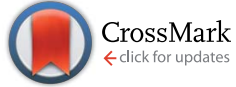

Cite this: RSC Adv., 2017, 7, 5251

\title{
Multifunctional graphene quantum dots for combined photothermal and photodynamic therapy coupled with cancer cell tracking applications $\dagger$
}

\author{
Mukeshchand Thakur, Mukesh Kumar Kumawat and Rohit Srivastava*
}

Graphene quantum dots (GQDs) have gained enormous attention due to their unique optical properties and emerging employment in biology. Herein, we report the synthesis of highly crystalline GQDs having superior physicochemical and near infrared (NIR)-responsive properties using simple waste, withered leaves of Ficus racemosa, an Indian fig tree, as a carbon source. A considerably large production yield was obtained (ca. 18\%) with a competitive quantum yield of $14.16 \%$. The GQDs exhibited excellent dispersibility in both organic as well as aqueous solvents and were highly photostable. High-resolution transmission electron microscopy showed the presence of ultra-small honeycombed as well as self-assembled GQDs. Cell cycle analysis using flow cytometry and biocompatibility studies showed that the GQDs were cytocompatible and were used as in situ labeling probes for normal as well as cancer cells. Furthermore, upon irradiation with an $808 \mathrm{~nm}$ laser $\left(0.5 \mathrm{~W} \mathrm{~cm}^{-2}\right)$, a concentration-dependent photothermal response and production of reactive oxygen species were observed. Confocal laser scanning microscopy showed that GQDs did not lose their fluorescence despite continuous laser irradiation (30 min) on MDA-MB-231 breast cancer cells. Thus, cell death could be traced using GQD-labeled MDA-MB-231 cells post-therapy using the photostability of GQDs, unlike photo-bleachable organic dyes. Thus, a low-cost, scalable, greensynthesis of GQDs with highly efficient optical properties will pave the way for new therapeutics and imaging in biomedical cancer research.

Received 28th October 2016 Accepted 3rd January 2017

DOI: 10.1039/c6ra25976f

www.rsc.org/advances

\section{Introduction}

Graphene quantum dots (GQDs) have attained a prominent position in biomedical research owing to their excellent physical, chemical, optical, and electronic properties. ${ }^{1,2}$ The GQDs are zero-dimensional carbon nanomaterials holding intrinsic photoluminescence, ${ }^{3}$ good dispersibility in aqueous and organic solvents, ${ }^{4,5}$ high photostability, ${ }^{6}$ excitation-dependent and excitation-independent luminescence, ${ }^{1,7}$ and large molar extinction coefficients, ${ }^{8}$ owing to such excellent properties the GQDs have been employed for widespread applications, for instance, Wang et al. showed that there is a myriad of publications reported on GQD-based research and their application. ${ }^{9}$ This is primarily due to their low toxicity and resistance to photo-bleaching as compared to semiconductor quantum dots

Department of Biosciences and Bioengineering, Indian Institute of Technology Bombay, Mumbai, India. E-mail: rsrivasta@iitb.ac.in; Fax: +91-22-2572-3480; Tel: +91-222576-7746

$\dagger$ Electronic supplementary information (ESI) available: High resolution LCMS spectra, XRD, yeast bioimaging, and cell photoluminescence studies. See DOI: 10.1039/c6ra25976f of group II-VI which require highly toxic heavy-metal elements ${ }^{10,11}$ and photo-bleaching organic dyes respectively. ${ }^{12,13}$

Current research on fluorescent carbon nanomaterials has been focused on the GQDs, carbon dots (C-dots), carbon nanodiamonds, and carbon nano-onions. ${ }^{14}$ The GQDs fabricated with non-toxic carbon-based precursors have decent quantum yield and are scalable. ${ }^{15,16}$ Thus, they are becoming a choice of nanomaterials for imaging in biology and medicine. Numerous synthesis procedures have been reported ${ }^{1,7}$ with commonly employed methods being thermal treatment based methods such as microwave-assisted or hydrothermal synthesis due to simplicity and efficiency. Carbon precursors used in fabricating GQDs can be classified as chemical and biological, ${ }^{7}$ the former demanding the use of harsh chemicals and multiple purification steps. Biological or natural precursors are cheap and environmental-friendly leading to 'green-synthesis' based approaches for obtaining the GQDs with high-yield. Recently, natural precursors have been used for green-synthesis of GQDs prominent ones include such as phyto-extracts and fruits, ${ }^{17-20}$ rice-husk, ${ }^{21}$ milk, ${ }^{22}$ and leaves. ${ }^{23}$ The quest for green precursors is, therefore, increasing due to their non-toxicity, easy handling, large-scale availability, low-cost, and helps in recycling waste 
products into valuable products. To achieve this, there is a need for a continuous supply of such green precursors regardless of environmental conditions such as atmospheric temperature and availability. In this context, we selected Ficus racemosa (an Indian fig tree), which is well-known tropical tree for its diverse medicinal properties such as anti-oxidant, anti-fungal, antimicrobial, anti-inflammatory, and anti-diabetic. ${ }^{24-26}$ Different parts of the tree such as leaves, stem bark and plant sap, have been known to possess pharmacologically active constituents. ${ }^{26}$ F. racemosa tree produces the considerably large amount of withered leaves as waste products year-round which could serve as a potential carbon source. We show that the waste withered leaves of $F$. racemosa serve as an economical and excellent carbon precursor for the GQDs synthesis irrespective of growth season or external environmental perturbations. Furthermore, the as-synthesized GQDs showed wide-absorption in NIR spectrum and gave a photothermal and photodynamic response to NIR laser (808 nm). In comparison to the semiconductor QDs or organic dyes, these GQDs are biocompatible to healthy cells and did not lose its fluorescence upon laser exposure for a long time depicting their photostability.

Since much research on photothermal response is usually focused on metallic gold-based nanomaterials, ${ }^{27,28}$ very few research has been done on chemically fabricated GQDs for photodynamic-based therapies due to their production of singlet oxygen species upon laser exposure. ${ }^{29-31}$ Wang et al. showed synthesis of GQDs from carbon black have shown temperature sensitivity although in synergism with aptamer, for selective cancer cell labelling and photothermal ablation of cells. $^{32}$ In this report, we show both photothermal as well photodynamic response to NIR $808 \mathrm{~nm}$ laser on MDA-MB-231 breast cancer cells using a green-synthesized GQDs. To the best of our knowledge, this is the first report to highlight intrinsic fluorescence of GQDs from an economically viable carbon precursor such as withered leaves for photothermalcum-photodynamic therapy and cell tracking which is rather difficult to achieve with respect to conventional dyes.

\section{Experimental}

\subsection{Pre-processing of withered leaves and synthesis of GQDs}

Withered leaves of $F$. racemosa were collected from the campus of IIT Bombay, India. The leaves were washed with Milli-Q water $(\mathrm{pH} 6.5,18 \mathrm{~m} \Omega)$ to remove the traces of dust and particulates. The leaves were then dried in an oven at $50{ }^{\circ} \mathrm{C}$ for $20 \mathrm{~min}$ and then crushed using mortar and pestle by adding liquid nitrogen $\left(\mathrm{N}_{2}\right)$ to obtain a fine powder. Briefly, $10 \mathrm{~g}$ of fine leaf powder was mixed in Milli-Q (10 mL) and was sonicated ( $40 \mathrm{kHz}$ ) for $15 \mathrm{~min}$. The solution was transferred to a Teflon-coated autoclave and heated in an oven at $180{ }^{\circ} \mathrm{C}$ for various time periods $(2 \mathrm{~h}, 4 \mathrm{~h}, 6 \mathrm{~h}$ and $8 \mathrm{~h}$ ) to monitor the reaction progress. The resultant brown colored carbonized product obtained after $8 \mathrm{~h}$ was treated with $\mathrm{NaOH}\left(5 \mathrm{~mL}, 0.1 \mathrm{M}\right.$ ) and purified using a dialysis membrane ${ }^{33}$ with molecular weight cut-off (MWCO): 12-14 kDa. After dialysis, the solution was subjected to freeze-drying for $24 \mathrm{~h}$ to obtain a fine powder of pure GQDs.

\subsection{Production yield (PY) and quantum yield (QY) of GQDs}

A PY was calculated using the purified final weight (FW) in grams $(\mathrm{g})$ to the initial weight, IW of leaf powder used as a carbon precursor. ${ }^{34}$ The percentage production yield (\% PY) was calculated as per following eqn (A):

$$
\% \mathrm{PY}=\mathrm{FW}(\mathrm{g}) / \mathrm{IW}(\mathrm{g}) \times 100
$$

For QY measurement, quinine sulfate (QS) solution in $\mathrm{H}_{2} \mathrm{SO}_{4}$ (50 $\mathrm{mM}$ ) was considered as a standard, and GQDs solution in Milli-Q with PL intensity was obtained by dilution to avoid any re-absorption effect. The QY was calculated using eqn (B) ${ }^{35}$ as follows:

$$
\Phi_{\mathrm{GQDs}}=\Phi_{\mathrm{QS}} A_{\mathrm{QS}} I_{\mathrm{GQDs}} \eta_{\mathrm{GQDs}}{ }^{2} / A_{\mathrm{GQDs}} I_{\mathrm{QS}} \eta_{\mathrm{QS}}{ }^{2}
$$

where, $\Phi$ is the QY, $A$ is the absorbance $(<0.1), I$ is the integrated PL intensity, $\eta$ is the refractive index of solvent in which GQDs and QS were dispersed.

\subsection{Cell culture and biocompatibility}

Mouse fibroblasts normal cells: L929 cell line was procured from National Centre for Cell Sciences (NCCS) Pune, India. Cells were grown in DMEM medium and maintained at $5 \% \mathrm{CO}_{2}$ and $37{ }^{\circ} \mathrm{C}$ temperature. Biocompatibility study was performed on L929 cell line using an MTT assay. ${ }^{36}$ Briefly, cells were seeded at a concentration 8000 cells per well in a 96-well plate for MTT-based assay using 3-(4,5-dimethylthiazol-2-yl)-2,5-diphenyltetrazolium bromide dye and kept at $5 \% \mathrm{CO}_{2}$ at $37{ }^{\circ} \mathrm{C}$ with absorbance read at $570 \mathrm{~nm}$ and $620 \mathrm{~nm}$ as a reference wavelength. Cell viable fraction (VF) was calculated using following eqn (C), where $A$ is the difference in the calculated absorbance as follows:

$$
\mathrm{VF}=\frac{A_{\text {test }}-A_{\text {blank }}}{A_{\text {control }}-A_{\text {blank }}}
$$

\subsection{Bioimaging and cell cycle analysis}

Different cell lines: skin keratinocytes HaCaT cells, pancreatic cancer Mia-PaCa-2 cells, and breast cancer cell line MDA-MB231 were procured from National Centre for Cell Sciences (NCCS) Pune, India. Each cells were seeded onto a sterile coverslip with a density of 5000 cells per well in a 12-well plate. Cells were treated with GQDs ( $\mathrm{pH} 7,100 \mu \mathrm{g} \mathrm{mL} \mathrm{m}^{-1}$ ) for $2 \mathrm{~h}$. The cells were then fixed with paraformaldehyde $(2.7 \%)$ for $2 \mathrm{~min}$, followed by washing with PBS ( $\mathrm{pH} 7)$ and imaged at different excitation wavelength-blue $(405 \mathrm{~nm})$, green $(488 \mathrm{~nm})$, and red $(543 \mathrm{~nm})$ lasers respectively. Cellular localization and fluorescence emission were performed using CLSM at excitation/ emission wavelengths $488 / 520 \mathrm{~nm}$. For cell cycle analysis, $2 \times$ $10^{6}$ cells (normal L929 cells and cancer MDA-MB-231 cells) were incubated for $24 \mathrm{~h}$ at $5 \% \mathrm{CO}_{2}$ and $37{ }^{\circ} \mathrm{C}$. The cells were then seeded with GQDs $\left(0.1 \mathrm{mg} \mathrm{mL}{ }^{-1}\right)$ for $24 \mathrm{~h}$. The cells were then washed, trypsinized, and dispersed in PBS ( $\mathrm{pH} 7.0)$ with PI $\left(50 \mu \mathrm{g} \mathrm{mL}^{-1}\right)$ and RNase A $\left(100 \mu \mathrm{g} \mathrm{mL}^{-1}\right)$ and kept in dark for $15 \mathrm{~min}$ before flow cytometry analysis. A minimum of 10000 events were recorded for each analysis. 


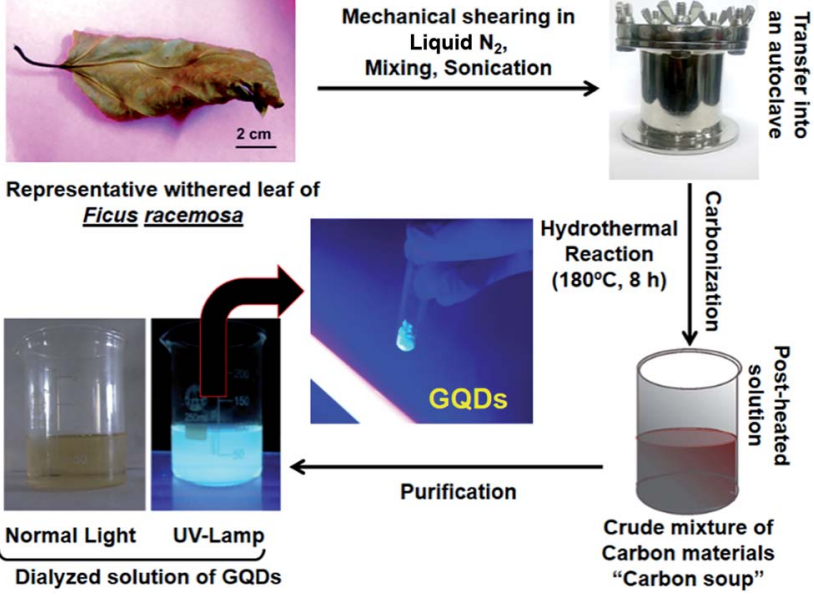

Fig. 1 A general workflow towards synthesis, extraction, and purification of multi-luminescent GQDs from withered leaves of $F$. racemosa. Withered leaves of $F$. racemosa crushed in liquid $\mathrm{N}_{2}$ followed by thermal disintegration undergo carbonization in a hydrothermal reaction chamber. The resultant crude mixture is a soup of different types of carbon nanomaterials which was further subjected to purification steps and freeze-drying to attain solid-state GQDs.

\subsection{Photothermal response study of GQDs}

For photothermal therapy, different concentration of GQDs was treated with NIR $808 \mathrm{~nm}$ laser $\left(0.5 \mathrm{~W} \mathrm{~cm}^{-2}\right)$ for $5 \mathrm{~min}$ at an operating distance of $1 \mathrm{~cm}$ on a $5 \mathrm{~mm}$ spot size. Photothermal
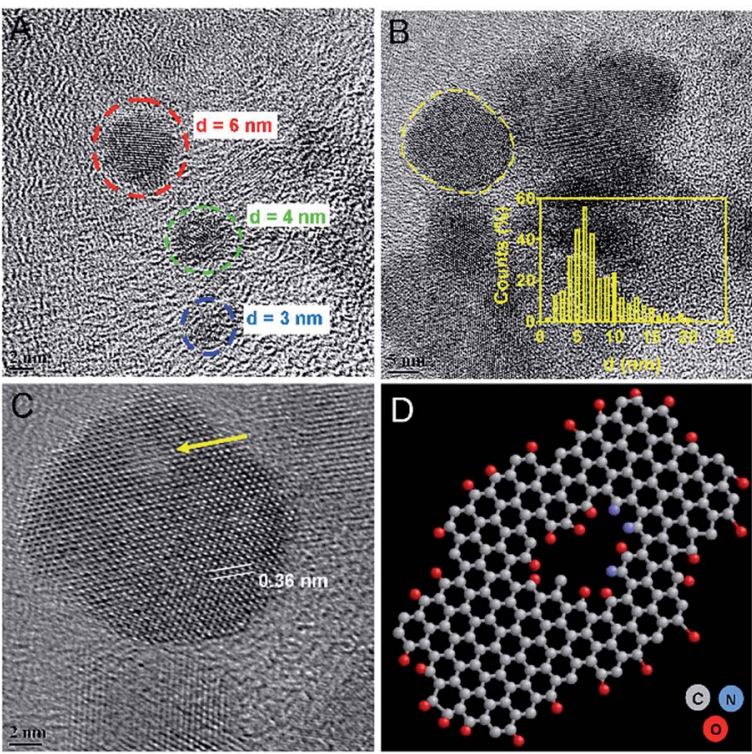

Fig. 2 Morphological analysis of GQDs from withered leaves. TEM image showing (A) ultra-small GQDs of diameter: $3 \mathrm{~nm}, 4 \mathrm{~nm}$, and $6 \mathrm{~nm}$ (color labeled) and (B) the existence of GQDs in cluster form with inset showing size distribution. (C) HRTEM of a single crystalline GQD (marked in B) with a honey-comb-like structure of graphene with few basal/edge state-defects shown with an arrow. Inset here shows lattice spacing distance. (D) Ball and stick model indicating the defect in a typical structure of GQD with self-passivated functional groups. The structure was sketched using ChemSketch and visualized using RasWin. temperature rise was recorded using a digital thermometer. For photothermal experiment, MDA-MB-231 cells were seeded at a density of $2 \times 10^{6}$ cells per $\mathrm{mL}$ for $24 \mathrm{~h}$ at $5 \% \mathrm{CO}_{2}$ at $37^{\circ} \mathrm{C}$. The cells were washed with PBS ( $\mathrm{pH} 7)$ and treated with GQDs $(1 \mu \mathrm{g}$ $\mathrm{mL}^{-1}$ to $250 \mu \mathrm{g} \mathrm{mL}^{-1}$ ) for $12 \mathrm{~h}$, followed by washing the cells and NIR $808 \mathrm{~nm}$ laser irradiation for $5 \mathrm{~min}$. Cell cytotoxicity was then calculated using standard MTT assay. ${ }^{36}$

\subsection{ROS analysis of GQDs}

The production of ROS was analyzed by using $2^{\prime}, 7^{\prime}$-dichlorofluorescin diacetate (DCFDA, Sigma-Aldrich; $50 \mu \mathrm{M}$ ) by taking fluorescence excitation at $495 \mathrm{~nm}$ and emission at $520 \mathrm{~nm}$ of GQDs treated or untreated cells (PBS, pH 7.0) for $30 \mathrm{~min}$. ROS generation was analysed at different time intervals relative to untreated L929 and MDA-MB-231 cells. Electron spin resonance (ESR) analysis was done at room temperature using $100 \mu \mathrm{g}$ $\mathrm{mL}^{-1}$ GQDs in aqueous solution using JES-FA200 ESR spectrometer with $\mathrm{X}$ and $\mathrm{Q}$ band at a standard frequency ( $\mathrm{X}$ band) of 8.75-9.65 GHz.

\subsection{Cell tracking and photostability analysis of GQDs}

Cellular tracking was performed by CLSM imaging at regular time intervals: $12 \mathrm{~h}, 18 \mathrm{~h}$, and $24 \mathrm{~h}$. A CLSM imaging was carried
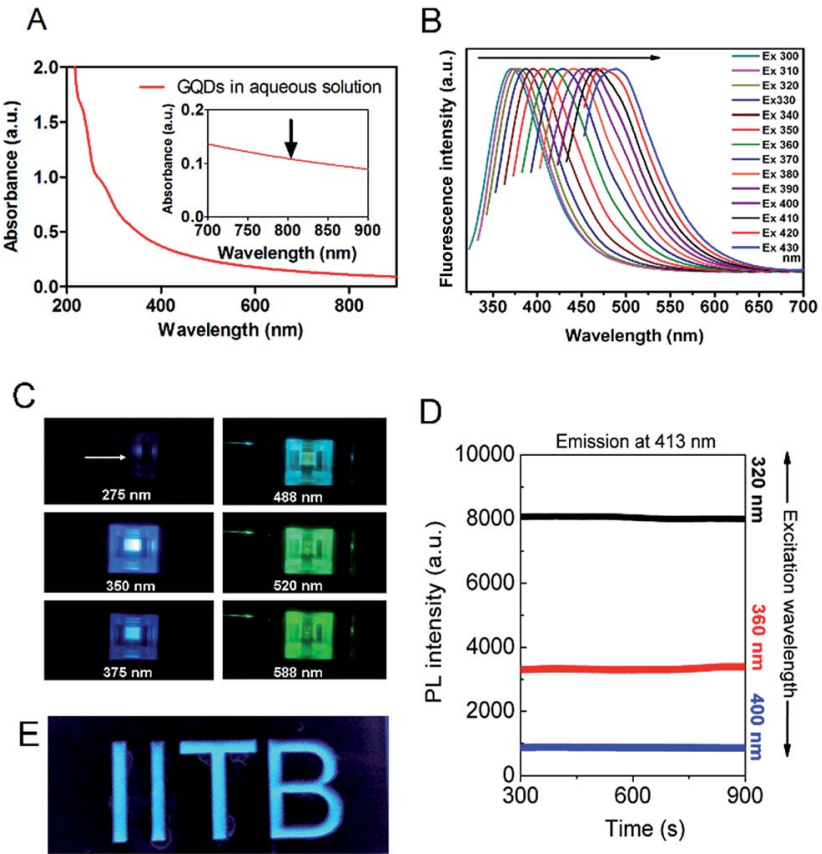

Fig. 3 (A) Absorption characteristics of GQDs (10 $\mu \mathrm{g} \mathrm{mL}^{-1}$ ) showing strong wide absorption around $230-320 \mathrm{~nm}$ and a wide absorption band from 700-900 nm (inset). (B) Excitation-dependent emission from GQDs excited at different wavelengths spanning from UV-region towards NIR spectrum. (C) Pictorial snapshots showing different emission colours (arrow pointed) upon excitation at various wavelengths (shown below over each cuvette in the inset), (D) fluorescence stability of GQDs showing linear photo-emission (at fixed $413 \mathrm{~nm}$ ) upon excitation at different wavelengths $(320 \mathrm{~nm}, 360 \mathrm{~nm}$, and 400 $\mathrm{nm}$ ) for continuous time period of $30 \mathrm{~min}$. (E) GQDs as fluorescent ink, embedded into an acrylic mould shaped into 'IITB' alphabets. 
out by excitation at $488 \mathrm{~nm}$ and emission at $520 \mathrm{~nm}$. Fluorescence stability study was conducted by exciting GQDs upon excitation at different wavelengths: $320 \mathrm{~nm}, 360 \mathrm{~nm}$, and $400 \mathrm{~nm}$, and recorded at a fixed emission wavelength, $413 \mathrm{~nm}$ for $30 \mathrm{~min}$.

\subsection{Instrumentation}

UV-Vis spectroscopy was performed at a path length of $1 \mathrm{~cm}$ using Perkin Elmer Lamda-25. Fluorescence spectroscopy was performed using Shimadzu at a slit width of $5 \mathrm{~nm}$ (excitation and emission) in high sensitivity mode. Morphological studies were performed using High-resolution Field-Emission Gun Transmission Electron Microscopy (FEG-TEM), Transmission Electron Microscopy (TEM) Philips CM200, and cryo-TEM (JEOL). Fourier Transform Infrared spectroscopy (FTIR) was done using 3000 Hyperion Microscope with Vertex 80 FTIR System (Bruker, Germany). X-ray diffraction (XRD) was performed using PANalytical. Raman spectra were recorded using a Jobin-Yvon Labram spectrometer. Samples were excited using $532 \mathrm{~nm}$ laser at $5 \mathrm{~mW}$. Dynamic light scattering and zeta potential analysis were done using (DLS)-BI200SM, Brookhaven Instruments Corporation, USA. X-ray Photoelectron Spectroscopy (XPS) was performed using a monochromatic Al K-alpha source $(225 \mathrm{~W})$ with a Kratos Analytical, UK (Model AXIS Supra). Fluorescence microscopy was carried out with three filter systems: 465-95, 540-25 and 540-80 nm using an Inverted Fluorescent Microscope: Nikon Eclipse TE 2000-S. Confocal laser scanning microscopy (CLSM) was performed using (Olympus, Flowview). The quantification of ROS was done on a microplate reader (Infinite 200 PRO, Tecan, Sweden).

\section{Results and discussion}

\subsection{Gram scale synthesis of GQDs}

Fig. 1 shows general steps employed during synthesis and purification of GQDs. Mechanical shearing and sonication ensure proper disintegration of coarse particles and heating at $180{ }^{\circ} \mathrm{C}$ leads to a process of "carbonization", which will further degrade the carbon products into smaller carbon materials and further reduce to form nanomaterials. ${ }^{37}$ The GQDs were extracted and purified by dialysis and the powdered form was obtained by freeze-drying. As seen in Fig. 1, the GQDs powder was luminescent under UV-exposure (365 nm). About $1.8 \pm 0.4 \mathrm{~g}$ of pure GQDs was harvested, and PY was $18.23 \%$ which was comparative to other green carbon sources. ${ }^{34}$ Calculated QY obtained was $14.16 \pm 0.3 \%$ (eqn (B)). The different plant constituents present in an aqueous extract of $F$. racemosa leaves were analysed using High Resolution Liquid Chromatography Mass Spectroscopy (HR-LCMS) showing various components such as amino acids, organic acids, lipids and flavonoids (Fig. S1 and Table S1†).

\subsection{Physicochemical and optical properties of GQDs}

A plethora of carbon nanomaterials is formed during carbonization process (referred to as carbon soup), comprising amorphous carbon, carbon nano-onions, GQDs, and carbon nanofibers. Morphological analysis of carbon soup using TEM and cryo-SEM analysis revealed the presence of other carbon nanomaterials formed during the formation of GQDs. Fig. S2 $\dagger$ shows the incompletely carbonized carbon in the shape of GQDs, carbon nanospheres, carbon nano-onions, branched carbon nanostructures and carbon nano-fibers which could be
A

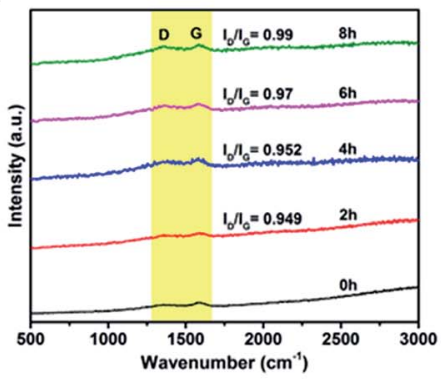

D

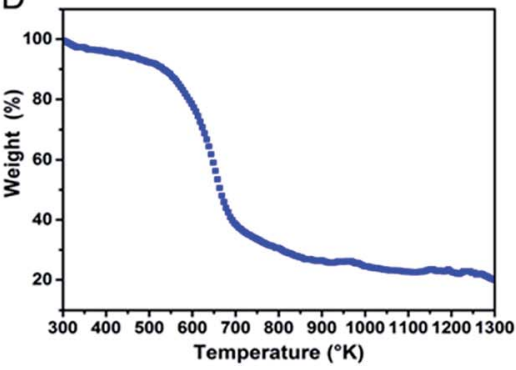

B

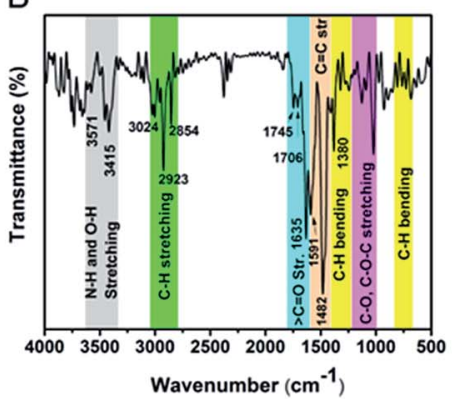

C

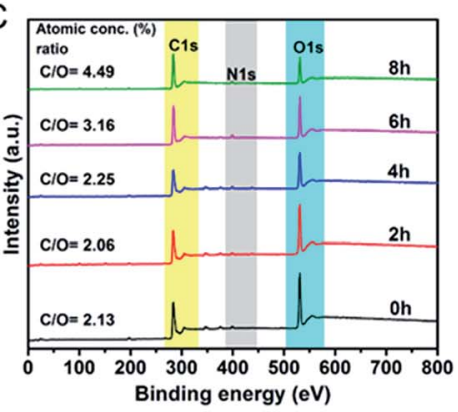

E

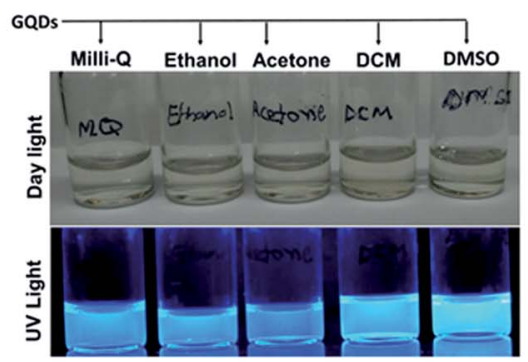

Fig. 4 Physical characterization of GQDs. (A) Raman spectrum recorded at the different hydrothermal reaction, (B) FTIR analysis, and (C) comparative survey XPS analysis showing N-doped characteristics and highly oxygen-rich surface, (D) TGA analysis, and (E) dispersion of GQDs in different solvents $\left(1.0 \mathrm{mg} \mathrm{mL}^{-1}\right)$. 
removed after purification of the crude material. Morphological features of purified GQDs were assessed using TEM analysis shows that the ultra-small and rounded GQDs were present in well dispersed as well as in irregular cluster forms (Fig. 2A and B). Recently, evidence of GQDs in the form of clusters has been envisaged, possible mechanisms of which have been attributed to solvent-assisted self-assembly, weak electrostatic interactions, and affinity between surface functional groups similar in this case. ${ }^{38-40}$ The GQD showed a crystalline honey-comb like structure (Fig. 2C, labelled from Fig. 2B) with surface defects and edge-effects in the structure. The size distribution analysis showed GQDs (Fig. 2B inset) of ultra-small diameters such as 2$8 \mathrm{~nm}$ and few self-assembled GQDs structures. The zeta potential measurement $(-35 \pm 3.2 \mathrm{mV})$ showed that the GQDs were negatively charged and highly stable.

The absorption spectra of GQDs showed strong absorption around $230 \mathrm{~nm}$ and $320 \mathrm{~nm}$ (Fig. 3A) with a wide absorption in NIR region (inset). UV-absorption is due to $\pi-\pi^{*}$ and $n-\pi^{*}$ electronic transitions within the structure. These transitions arise due to $\mathrm{C}=\mathrm{C}$ bonds and oxygen and nitrogen containing functional groups present in the structure. ${ }^{\mathbf{4 1 , 4 2}}$ The carbon soup showed stronger absorption from UV and extended into visible region (Fig. S3a $\dagger$ ). By controlling the degree of carbonization using a hydrothermal route, control over the synthesis of different carbon based nanomaterials such as GQDs has been envisaged. ${ }^{37}$ These diverse forms of carbon nanomaterials are

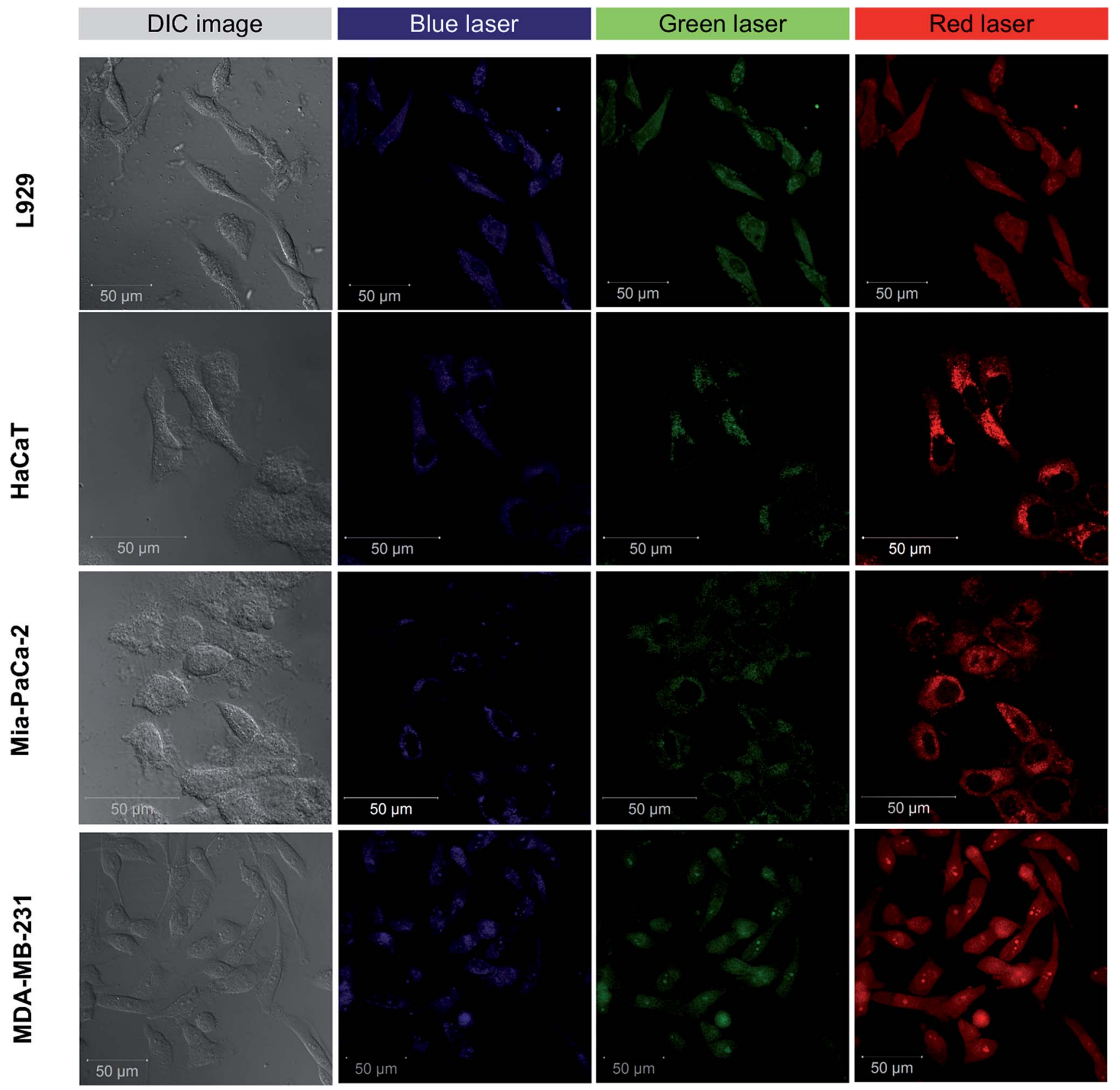

Fig. 5 Multi-colour CLSM imaging of L929 cells, HaCaT cells, Mia-PaCa-2 cells, and MDA-MB-231 cells labeled with GQDs. 
an intermediate by-product formed during the process of GQDs formation.

To understand the defective states and chemical composition of the GQDs, Raman spectroscopy, FTIR, CHNOS elemental analysis, and XPS were performed. In Fig. 4A, Raman spectrum clearly revealed the presence of D-band $\left(1353 \mathrm{~cm}^{-1}\right)$, and G-band $\left(1581 \mathrm{~cm}^{-1}\right)$. Pure graphene shows only graphitic, or G-band and rise of $\mathrm{D}$ - or disordered band (also referred to as breathing mode) is a clear indicative of defects in the carbon structure. ${ }^{43-45}$ The G-band is an attribute of $\mathrm{sp}^{2}$ carbon whereas D-band is due to the defects brought by introduction of $\mathrm{sp}^{3}$ carbon clusters. As the reaction progresses from $2 \mathrm{~h}$ to $8 \mathrm{~h}$, the increase in the $I_{\mathrm{D}} / I_{\mathrm{G}}$ ratio from 0.94 to 0.99 indicates the quantitative growth of graphitic domains containing $\mathrm{sp}^{2}$ hybridized carbons though the average size of defect-free areas remains less due to increased number of $\mathrm{sp}^{3}$ hybridized carbons. ${ }^{46}$ These defects are in accordance with the HRTEM image shown in Fig. 2C and D. The XRD spectrum (Fig. S3b $†$ ) showed a peak around $23.72^{\circ}$ is due to graphitic [022] plane indicating crystallinity of GQDs synthesized by a hydrothermal route. ${ }^{47}$ The AFM image analysis of GQDs were multi-layered structures of a thickness of 7-10 nm (Fig. S4 $\dagger$ ).

The FTIR spectra revealed oxygen-rich functional groups on self-passivized GQDs (Fig. 4B). These functional groups (Table S2 $\dagger$ ) are reportedly present in the constituents of $F$. racemosa leaves like flavonoids, tannins, alkaloids, and triterpenoids (lanosterol, racemosic acid, etc.) and hence heritably appears in the FTIR spectrum of GQDs. ${ }^{48}$ The IR bands at $1745 \mathrm{~cm}^{-1}, 1706 \mathrm{~cm}^{-1}$, and $1635 \mathrm{~cm}^{-1}$ are due to the presence of $\mathrm{C}=\mathrm{O}$ bond from carboxylic, ketonic and amide groups respectively. These functional groups provide solubility as well as enhancement in fluorescence owing to oxygen and nitrogen atoms naturally doped in the GQD-structure., ${ }^{1,74,48}$ The peaks appeared at $2854 \mathrm{~cm}^{-1}, 2923 \mathrm{~cm}^{-1}$, and $3024 \mathrm{~cm}^{-1}$ are corresponding to $\mathrm{C}-\mathrm{H}$ stretching vibrations from $\mathrm{sp}^{2}$ and $\mathrm{sp}^{3}$ hybridized carbon atoms. The peaks after $3400 \mathrm{~cm}^{-1}$ observed due to $\mathrm{N}-\mathrm{H}$ and $\mathrm{O}-\mathrm{H}$ stretching vibrations. The graphitic skeleton which caused $\mathrm{C}=\mathrm{C}$ stretching vibrations at $1591 \mathrm{~cm}^{-1}$ and 1482 $\mathrm{cm}^{-1}$. The peaks appeared in between $1000-1300 \mathrm{~cm}^{-1}$ correspond to $\mathrm{C}-\mathrm{O}$ and $\mathrm{C}-\mathrm{O}-\mathrm{C}$ stretching vibrations. Elemental CHNOS analysis showed the percentage composition of $\mathrm{C}, \mathrm{H}, \mathrm{N}, \mathrm{S}$, and $\mathrm{O}$ as $78.8 \%, 4 \%, 0.4 \%, 0.2 \%$, and $15.1 \%$ respectively. A comparative analysis of XPS survey spectra showed the presence of carbon, oxygen, and nitrogen atoms during the full course of the reaction where the $\mathrm{C} / \mathrm{O}$ atomic concentration (\%) ratio gradually increases from 2.13 to 4.49 (Fig. 4C and S5 $\dagger$ ). A comparative analysis of deconvoluted C1s XPS spectra recorded at various time periods of the reaction reveals that $\mathrm{C}-\mathrm{C}$ binding energy peak initially gradually decreases whereas $\mathrm{C}=\mathrm{O}$ peak simultaneously increases thereby the increment in $\mathrm{C} / \mathrm{O}$ ratio is not significant (Fig. S6†). In later hours of reaction some loosely bonded oxygen-containing functional groups might have eliminated which subsequently causes the drastic increase in the relative $\mathrm{C}-\mathrm{C}$ peak intensity, therefore, C/O ratio reaches to 4.49. The peak around $292 \mathrm{eV}$, a shake-up satellite peak, confirms the presence of aromatic moieties in the course of the reaction and $\pi-\pi^{*}$ transitions from the structure. ${ }^{49}$ The GQDs were naturally N-doped responsible for increment in the PL of GQDs. Leaves provide a lot of proteins and peptides (in native or denatured form) as shown in Fig. S1† contributing to carbon and rich nitrogen doping interface. These amino acids contribute to the graphitic nitrogen during the process of carbonization. ${ }^{34}$ The solubility and dispersibility of GQDs can be correlated to high oxygen content in the structure. A TGA analysis shows a gradual change in the weight under controlled thermal treatment. ${ }^{17}$ Fig. $4 \mathrm{D}$ show thermal stability of GQDs till $250{ }^{\circ} \mathrm{C}$ (mere $10 \%$ weight loss) and increasing weight losses thereafter till $400{ }^{\circ} \mathrm{C}(60 \%$ weight loss $)$ and slowly degrading

\section{L929}
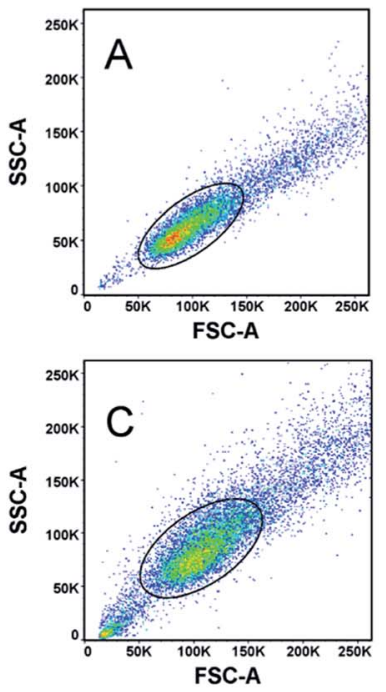
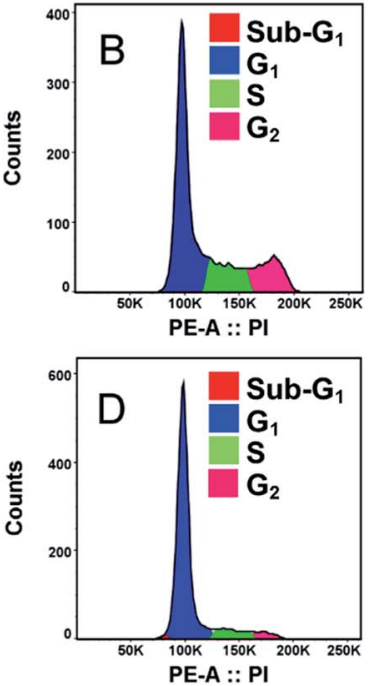

\section{MDA-MB-231}
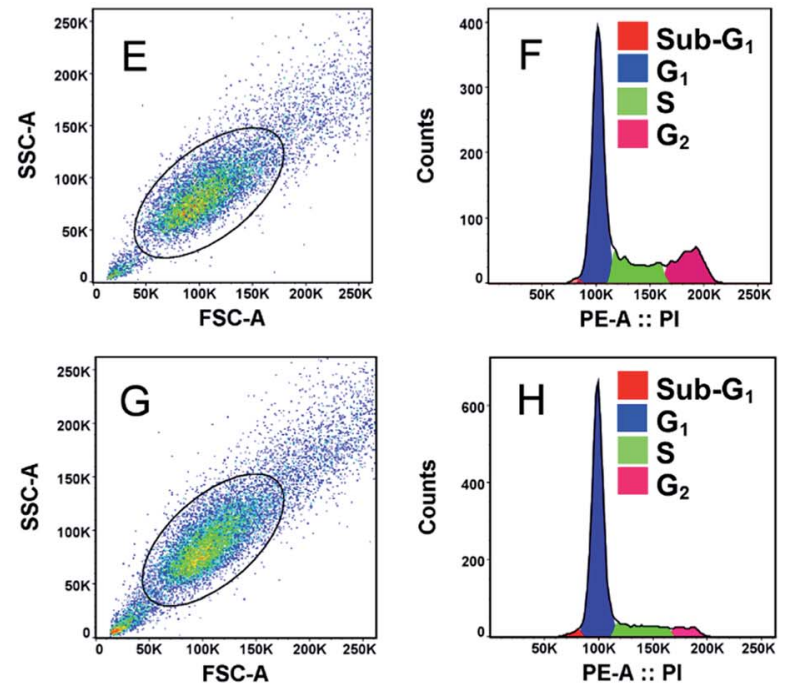

Fig. 6 Cell cycle analysis on L929 and MDA-MB-231 cells treated with GQDs (100 $\left.\mu \mathrm{g} \mathrm{mL}^{-1}\right)$ after $24 \mathrm{~h}$. Dot-plot showing cell size (FSC) and granularity (SSC-A), selected singlet cells, and corresponding cell growth phases of (A and B) control cells, (C and D) GQDs treated L929 cells while (E and F) represent MDA-MB-231 control cells and (G and H) represent GQDs treated MDA-MB-231 cells. 
after that. Furthermore, as shown in Fig. 4E, the GQDs are clearly dispersible in different solvents owing to their self-passivized surface groups.

\subsection{Bioimaging}

Initial experiments on labeling using GQDs were performed on Saccharomyces cerevisiae (commercially available Baker's yeast cells) were used as a model organism since they represent closer to mammalian cells (Fig. S7 $\dagger$ ). The CLSM microscopy showed multi-colour fluorescence properties of GQDs in mammalian cell lines. Fig. 5 shows multi-colour emission with different excitation in both normal and cancer cells in all the filters: blue, green, and red. The multi-colour emission is in accordance with the excitation-dependent emission property of these GQDs as
A

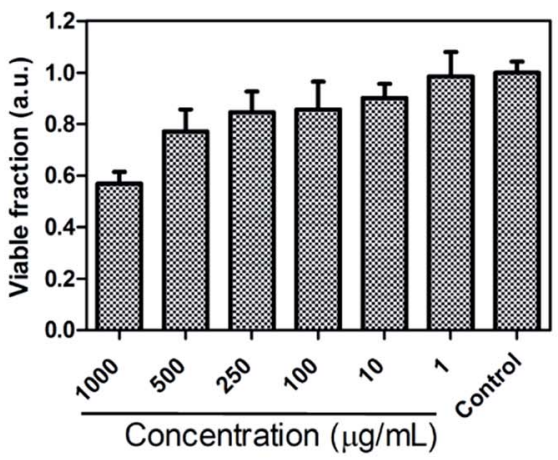

\section{B}

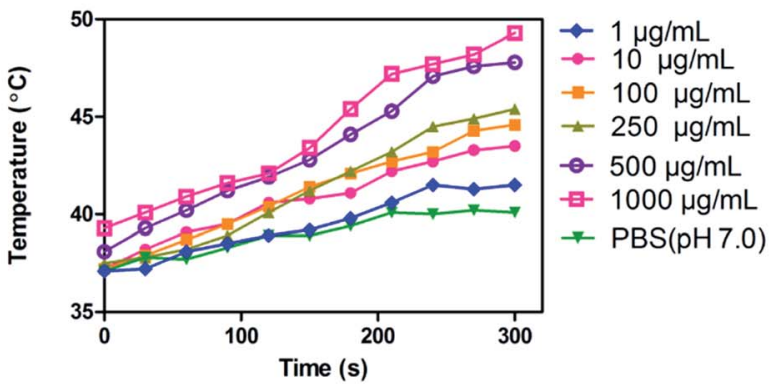

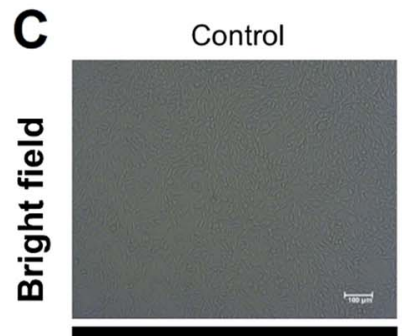
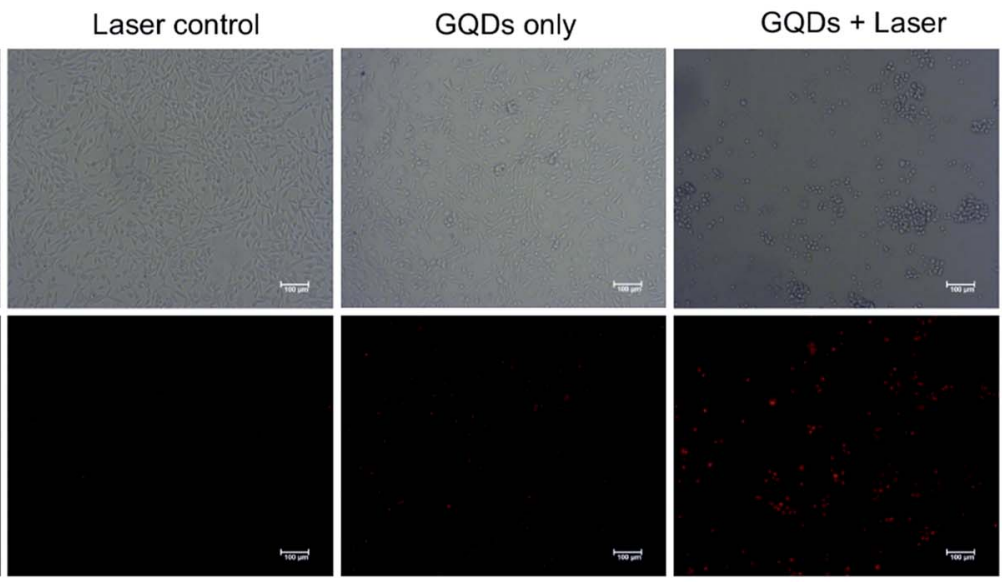

D

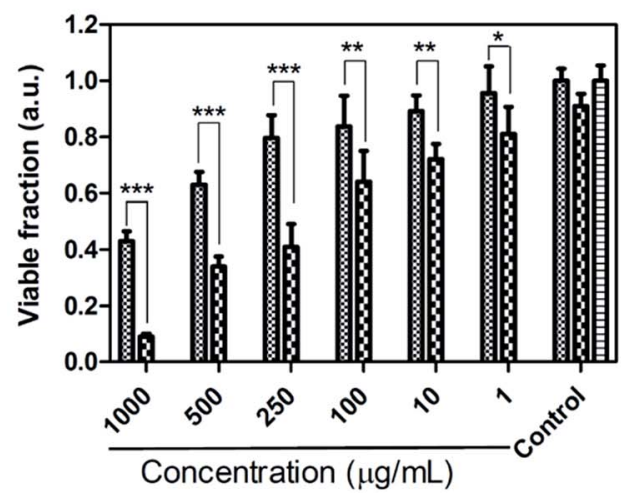

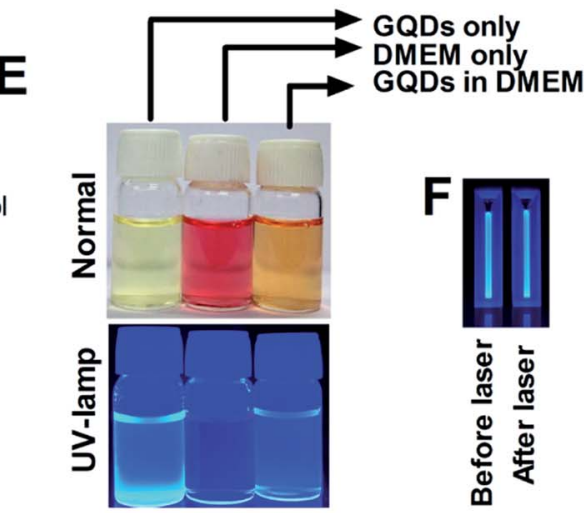

Fig. 7 Biocompatibility and photothermal activity of GQDs. (A) Cell viability analysis of L929 cells using a different concentration of GQDs ( $n=3$ ). (B) In vitro temperature increment of GQDs (1-1000 $\mu \mathrm{g} \mathrm{mL}^{-1}$ ) after irradiation with NIR laser (808 $\left.\mathrm{nm}, 0.5 \mathrm{~W}\right)$ for $5 \mathrm{~min}$, (C) qualitative cell cytotoxicity by PI staining of MDA-MB-231 breast cancer cells. (D) Photothermal effect of GQDs on MDA-MB-231 cells after laser treatment for 5 min $(n=3, * P<0.05, * * P<0.01, * * * P<0.001)$. (D) Media dispersibility and stability of GQDs in DMEM cell culture medium. (E) Fluorescence of GQDs under UV-excitation ( $375 \mathrm{~nm}$ ) before and after laser exposure for 5 min showing no apparent change in fluorescence. 
shown in Fig. 3B. To assess the applicability of GQDs in cellular imaging in different cells various cell lines were used as illustrated in Fig. 5. The GQDs entered cells within $2 \mathrm{~h}$ and successfully labelled both normal and cancer cells. The cellular internalization of GQDs were occurred possibly due to caveolaedependent endocytosis mechanism. ${ }^{50,51}$ The cells showed no change in morphology in their structure indicating favorable living conditions. In Fig. 5, most of the GQDs are localized in the cell cytoplasm with few entered inside the nucleus. The GQDs are also known to cause cell cytotoxicity by damaging DNA and up-regulating certain proteins involved in regulation of cell cycle. ${ }^{52,53}$ However, at low concentrations $\left(<100 \mu \mathrm{g} \mathrm{mL}^{-1}\right)$ GQDs are commonly non-toxic and thus can be used for bioimaging and therapeutic applications.

\subsection{Cell cycle analysis}

Cell division occurs through number of growth phases where cells are initially at resting or quiescent phase $\left(\mathrm{G}_{0}\right.$-phase $)$ which then enters an interphase gap 1 or $G_{1}$-phase. In $G_{1}$-phase, the cell mass increases and enters S-phase where DNA replication takes place. Following this phase, the cell enters mitosis (Mphase) and begin cytoplasmic division. ${ }^{54}$ After $G_{1}$ and $G_{2}$-phases there are cellular checkpoints (using CDK-cyclin proteins) that monitor abnormalities in chromosomes and arrest cell cycle progression under such circumstances referred to as cellcycle arrest. $^{55}$

Carbon nanomaterials have been shown to have effect on DNA during cell cycle growth phases. ${ }^{22,29,51,52,55,56}$ In this report, we elucidated effect of GQDs fabricated from withered leaves on cell cycle analysis of two representative cell lines: L929 cells and MDA-MB-231 (Fig. 6). Untreated control cells in L929 cells were selected from singlet cells channel (Fig. 6A) which were then deconvoluted into distinct cell phases (Fig. 6B). Upon treatment with GQDs $(100 \mu \mathrm{g}$ $\mathrm{mL}^{-1}$ ) after $24 \mathrm{~h}$ (Fig. 6C), the cell growth was abrogated in Sphase and $\mathrm{G}_{2}$-phase as evident in Fig. 6D. Similar results were obtained in case of MDA-MB-231 cells (Fig. 6E-H). The $\mathrm{S}$ - and $\mathrm{G}_{2}$-phase declined considerably in contrast to their untreated control cells. Thus, the GQDs at $100 \mu \mathrm{g} \mathrm{mL}^{-1}$ concentrations tend to cease DNA replication in both cell types thereby emphasizing their interaction with intracellular biomolecules.

\subsection{Biocompatibility study}

Biocompatibility analysis was performed on L929 cells at a different concentration of GQDs (1-1000 $\left.\mu \mathrm{g} \mathrm{mL}^{-1}\right)$. More than $80 \%$ of cell viability was observed even at a high concentration of $250 \mu \mathrm{g} \mathrm{mL}{ }^{-1}$. Previous studies of green-synthesized GQDs based cytotoxicity have shown similar results of high biocompatibility. ${ }^{31,32,35,38}$ After $500 \mu \mathrm{g} \mathrm{mL}^{-1}$, the cell death was prominent probably due to significant ROS generation by GQDs at relatively high concentration. The GQDs to produce ROS was analysed in subsequent studies. A recent study has demonstrated the toxic effects of higher content of GQDs via p58 MAPK and NFKB mediated-pathways, inducing apoptosis and autophagy. ${ }^{52}$ However, clinically relevant concentration of GQDs lies $<100 \mu \mathrm{g}$ $\mathrm{mL}^{-1}$ with which moderate level of imaging of cells has been achieved. .,43,51 $^{-10}$
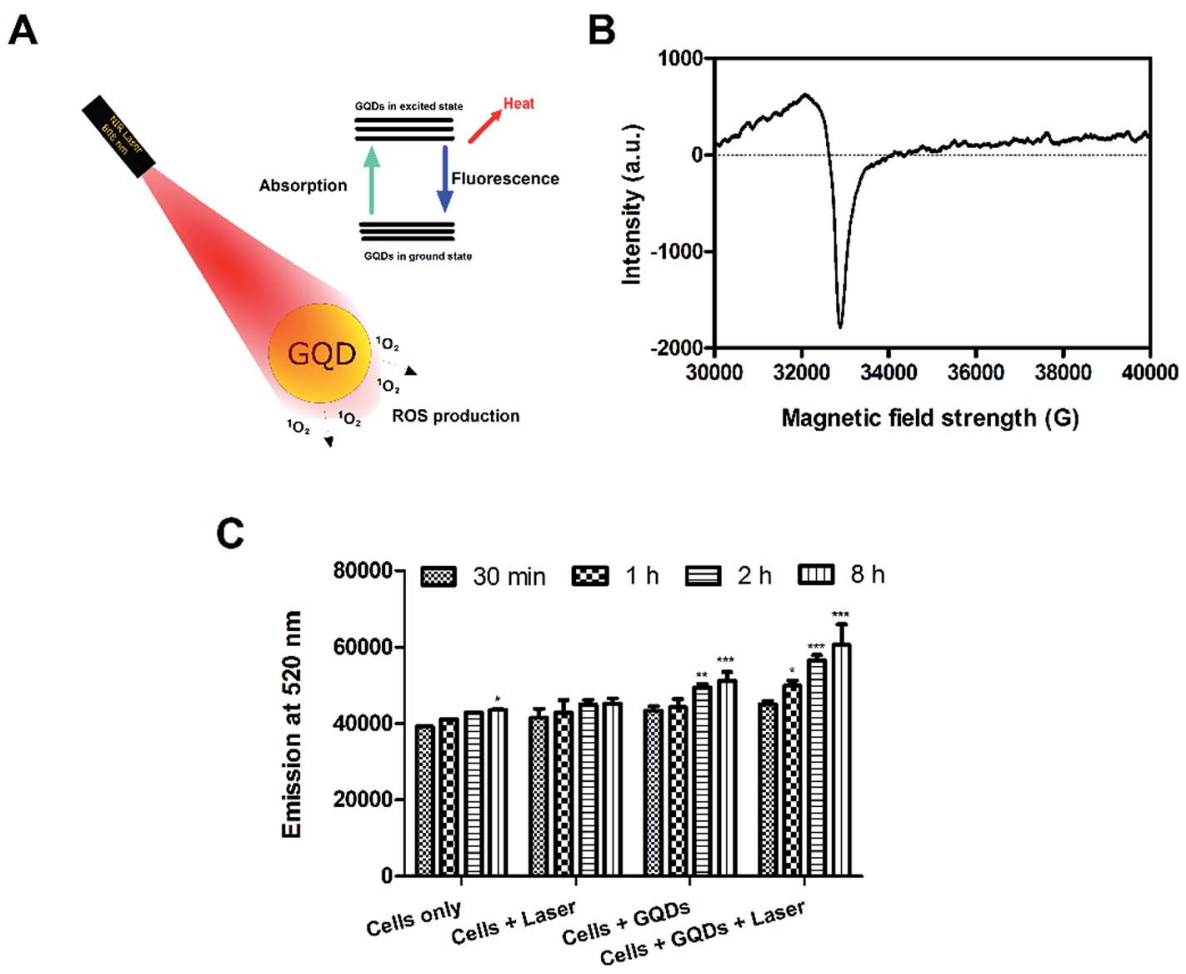

Fig. 8 Production of ROS using GQDs. (A) Schematic showing production of singlet oxygen species $\left({ }^{1} \mathrm{O}_{2}\right)$ upon irradiation with $808 \mathrm{~nm}$ laser. (B) An ESR signal of bare GQDs showing the presence of free electrons in the system, ROS production in (C) MDA-MB-231 cells. 


\subsection{Photothermal therapy, ROS effects and cell-tracking analysis}

The photothermal response of GQDs was tested using NIR laser ( $808 \mathrm{~nm}, 0.5 \mathrm{~W} \mathrm{~cm}^{-2}$ ) at an operating distance of $1 \mathrm{~cm}$ for $5 \mathrm{~min}$. In vitro photothermal temperature, the increment was observed with increasing concentration of GQDs in MDA-MB-231 cells (Fig. 7B). At a concentration of $100 \mu \mathrm{g} \mathrm{mL} \mathrm{m}^{-1}$ of GQDs, the temperature rises to $43{ }^{\circ} \mathrm{C}$, at $250 \mu \mathrm{g} \mathrm{mL} \mathrm{L}^{-1}$ the temperature rises to $45{ }^{\circ} \mathrm{C}$ and reaches $c a .49{ }^{\circ} \mathrm{C}$ at $1 \mathrm{mg} \mathrm{mL}^{-1}$ after $5 \mathrm{~min}$ of continuous laser irradiation. It has been envisaged that a hyperthermia of about $42{ }^{\circ} \mathrm{C}$ is a threshold temperature for inducing cell death by apoptosis in mammalian cells. ${ }^{57}$

Phototherapy in synergism with cytotoxicity of bare GQDs alone was analyzed on MDA-MB-231 breast cancer cell line. Laser induced cell death was observed, with less than $50 \%$ cell survival at dose $250 \mu \mathrm{g} \mathrm{mL} \mathrm{m}^{-1}$ and less than $10 \%$ at $1000 \mu \mathrm{g} \mathrm{mL}$ (Fig. 7D). Control cells (untreated), and cells treated with laser only or vehicle control (Milli-Q) did not affect cell viability. Recent few insights on laser therapy using GQDs have shown photothermal and photodynamic effects on cells either alone or in synergism with a therapeutic agent ${ }^{39,43,47}$ while this being the first to show bare GQDs to have potential photothermal property, further functionalization can achieve greater photothermal response. Application of GQDs in therapy, thus, needs more attention in biomedical application along with their bioimaging application. Photoluminescence of GQDs is affected by external solvent and ions such as $\mathrm{pH}$ conditions. ${ }^{1,2,23}$ Fig. $7 \mathrm{E}$ shows the pictorial representation of dispersibility and fluorescence ability of GQDs in aqueous as well as cell culture (DMEM) medium. Fig. 7F shows laser stability studied by exposing bare GQDs $\left(100 \mu \mathrm{g} \mathrm{mL} \mathrm{mL}^{-1}\right)$ with NIR laser $(808 \mathrm{~nm})$ and analyzing its fluorescence (Fig. S8 ${ }^{\dagger}$ ). No significant change in the photoluminescence was observed with a constant emission (till 30 min) was observed, showing excellent laser stability of GQDs even after long time laser exposure.

The photo-excited GQDs $(808 \mathrm{~nm})$ released heat (photothermal) and singlet oxygen species production (Fig. 8A). The GQDs possess free electrons within the structure as evident by an ESR signal (Fig. 8B) which arise from defects in the GQDs structure. ${ }^{29,35}$ As expected, in Fig. 8C, the GQDs labeled cells produced ROS with increasing incubation time after laser therapy thereby posing cytotoxic effects or photodynamic effects

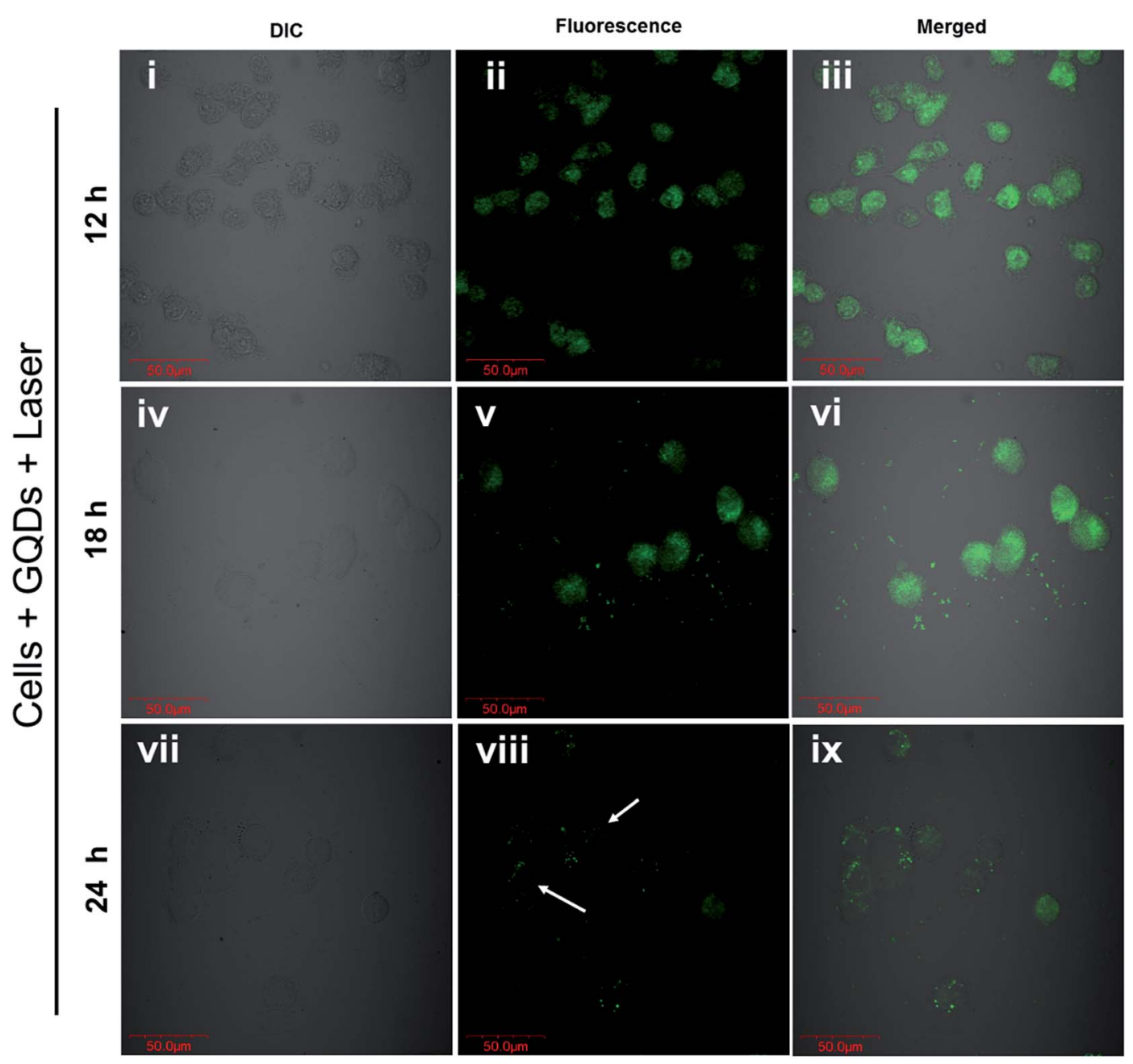

Fig. 9 Fluorescence-based cellular tracking of GQDs-tagged MDA-MB-231 cells using by time-lapsed CLSM imaging. Cells were treated with GQDs $\left(100 \mu \mathrm{g} \mathrm{mL}^{-1}\right.$ ) for $24 \mathrm{~h}$, followed by $808 \mathrm{~nm}$ laser irradiation for $5 \mathrm{~min}$, and imaged at different time intervals post-therapy. 
on MDA-MB-231 cells. These results corroborate with Fig. 7C and D. Few reports have shown production of ROS using GQDs fabricated by chemical methods ${ }^{35,51,52}$ whereas, in the current report, intracellular ROS production was observed from GQDs fabricated using a plant source for the first time. The GQDs can be used as dual photothermal and photodynamic agent coupled with imaging in medicine. Owing to high laser stability of GQDs, post-therapy cell imaging application was elucidated. Fig. 9 shows GQDs-labelled cancer cell tracking using CLSM after laser exposure $\left(808 \mathrm{~nm}, 0.5 \mathrm{~W} \mathrm{~cm}^{-2}\right)$ for $5 \mathrm{~min}$. The treated cells were imaged $12 \mathrm{~h}$ (i-iii), $18 \mathrm{~h}$ (iv-vi) and $24 \mathrm{~h}$ (vii-ix) with excitation/emission (488 nm/520 nm) wavelength. Upon laser irradiation, the combined hyperthermia and ROS causes an apparent change in the morphology of cells (Fig. 9i-iii). The cells now begin to gain round morphology and cell within $18 \mathrm{~h}$ (Fig. 9iv-vi), and cell debris can be seen after $24 \mathrm{~h}$ (Fig. 9vii-ix). These results corroborate with PI-based staining in Fig. 7C. The interesting fact, however, is that the fluorescence of GQDs was still apparent after $24 \mathrm{~h}$ of laser treatment after cell death. Thus, a high photostability of GQDs was elucidated after laser treatment (also see Fig. S9†).

Dead cell labeling is commonly carried out using PI for labeling pro-apoptotic cells. However, the major limitation with organic dyes is photobleaching, susceptibility to degradation, and cost. ${ }^{12}$ Photostable fluorescent probes like GQDs are of particular important in efficient intra-cellular biosensing ${ }^{23}$ and applications like photothermal laser therapies where the affected sites are to be monitored continuously during and after surgery. With an eco-friendly and waste material such as withered leaves of $F$. racemosa, an efficient cell-labelling probe utility based on photostable intrinsic fluorescence can pave the way for the development of economical and efficient theranostic nanomaterials system.

\section{Conclusions}

In summary, we report a large-scale production of high-quality crystalline GQDs with withered leaves using one-pot hydrothermal synthesis strategy. The GQDs showed excellent biocompatibility and multi-fluorescence property in yeast and ranges of mammalian cells. The GQDs were highly dispersible, thermally stable and photostable in nature. The GQDs was demonstrated to have photothermal as well as photodynamic properties and showed potent therapeutic activity in breast cancer cells. Also, GQDs showed excellent laser stability and were used to track cells post laser application and monitor their structural changes.

\section{Acknowledgements}

M. T. would like to acknowledge Department of Biotechnology (DBT) project code 14DBTIYBA002 and IITB Research Internship Award 2014-15 (14IRINTRN029) for financial support. Authors thank Dr Piyush Kumar for his insights in cell-based studies. Authors also acknowledge Industrial Research and Consultancy Centre (IRCC) and Centre for Research in Nanotechnology and Science (CRNTS) at IIT Bombay for Instrumentation support.

\section{Notes and references}

1 P. Miao, K. Han, Y. Tang, B. Wang, T. Lin and W. Cheng, Nanoscale, 2015, 7, 1586-1595.

2 K. Hola, Y. Zhang, Y. Wang, E. P. Giannelis, R. Zboril and A. L. Rogach, Nano Today, 2014, 9, 590-603.

3 Z.-C. Yang, M. Wang, A. M. Yong, S. Y. Wong, X.-H. Zhang, H. Tan, A. Y. Chang, X. Li and J. Wang, Chem. Commun., 2011, 47, 11615-11617.

4 H. Li, Z. Kang, Y. Liu and S.-T. Lee, J. Mater. Chem., 2012, 22, 24230-24253.

5 A. Talib, S. Pandey, M. Thakur and H.-F. Wu, Mater. Sci. Eng., $C, 2015,48,700-703$.

6 Z. Sheng Qian, X. Yue Shan, L. Jing Chai, J. Rong Chen and H. Feng, Nanotechnology, 2014, 25, 415501.

7 H. Li, Z. Kang, Y. Liu and S.-T. Lee, J. Mater. Chem., 2012, 22, 24230.

8 L. Wang, Y. Wang, T. Xu, H. Liao, C. Yao, Y. Liu, Z. Li, Z. Chen, D. Pan, L. Sun and M. Wu, Nat. Commun., 2014, 5, 5357.

9 J. Wang, H. S. Choi and Y. X. J. Wang, J. Thorac. Dis., 2015, 7, E201-E205.

10 V. Rombach-Riegraf, P. Oswald, R. Bienert, J. Petersen, M. P. Domingo, J. Pardo, P. Gräber and E. M. Galvez, Biochem. Biophys. Res. Commun., 2013, 430, 260-264.

11 K.-T. Yong and M. T. Swihart, Nanomedicine, 2012, 7, 1641-1643. 12 U. Resch-Genger, M. Grabolle, S. Cavaliere-Jaricot, R. Nitschke and T. Nann, Nat. Methods, 2008, 5, 763-775.

13 O. S. Wolfbeis, Chem. Soc. Rev., 2015, 44, 4743-4768.

14 J. Wen, Y. Xu, H. Li, A. Lu and S. Sun, Chem. Commun., 2015, 51, 11346-11358.

15 J. Peng, W. Gao, B. K. Gupta, Z. Liu, R. Romero-Aburto, L. Ge, L. Song, L. B. Alemany, X. Zhan, G. Gao, S. A. Vithayathil, B. A. Kaipparettu, A. A. Marti, T. Hayashi, J. J. Zhu and P. M. Ajayan, Nano Lett., 2012, 12, 844-849.

16 A.-M. Alam, B.-Y. Park, Z. K. Ghouri, M. Park and H.-Y. Kim, Green Chem., 2015, 17, 3791-3797.

17 A. Mewada, S. Pandey, S. Shinde, N. Mishra, G. Oza, M. Thakur, M. Sharon and M. Sharon, Mater. Sci. Eng., C, 2013, 33, 2914-2917.

18 C. Phadke, A. Mewada, R. Dharmatti, M. Thakur, S. Pandey and M. Sharon, J. Fluoresc., 2015, 25, 1103-1107.

19 S. Pandey, A. Mewada, G. Oza, M. Thakur, N. Mishra, M. Sharon and M. Sharon, Nanosci. Nanotechnol. Lett., 2013, 5, 775-779.

20 M. Thakur, S. Pandey, A. Mewada, V. Patil, M. Khade, E. Goshi and M. Sharon, J. Drug Delivery, 2014, 2014, 282193.

21 S. Pandey, A. Mewada, M. Thakur, S. Pillai, R. Dharmatti, C. Phadke and M. Sharon, RSC Adv., 2014, 4, 1174.

22 M. Thakur, A. Mewada, S. Pandey, M. Bhori, K. Singh, M. Sharon and M. Sharon, Mater. Sci. Eng., C, 2016, 67, 468-477.

23 M. K. Kumawat, M. Thakur, R. B. Gurung and R. Srivastava, ACS Sustainable Chem. Eng., DOI: 10.1021/acssuschemeng.6b01893.

24 A. K. Keshari, G. Kumar, P. S. Kushwaha, M. Bhardwaj, P. Kumar, A. Rawat, D. Kumar, A. Prakash, B. Ghosh and S. Saha, J. Ethnopharmacol., 2016, 181, 252-262. 
25 S. C. Mandal, T. K. Maity, J. Das, B. P. Saba and M. Pal, J. Ethnopharmacol., 2000, 72, 87-92.

26 H. C. Gorwadiya, R. M. Savalia, K. V. Vachhani, T. R. Desai and D. J. Pandya, Pharmacogn. J., 2010, 2, 16-20.

27 S. Sasidharan, D. Bahadur and R. Srivastava, RSC Adv., 2016, 6, 84025-84034.

28 A. K. Rengan, A. B. Bukhari, A. Pradhan, R. Malhotra, R. Banerjee, R. Srivastava and A. De, Nano Lett., 2015, 15, 842-848.

29 Z. M. Markovic, B. Z. Ristic, K. M. Arsikin, D. G. Klisic, L. M. Harhaji-Trajkovic, B. M. Todorovic-Markovic, D. P. Kepic, T. K. Kravic-Stevovic, S. P. Jovanovic, M. M. Milenkovic, D. D. Milivojevic, V. Z. Bumbasirevic, M. D. Dramicanin and V. S. Trajkovic, Biomaterials, 2012, 33, 7084-7092.

30 B. Z. Ristic, M. M. Milenkovic, I. R. Dakic, B. M. TodorovicMarkovic, M. S. Milosavljevic, M. D. Budimir, V. G. Paunovic, M. D. Dramicanin, Z. M. Markovic and V. S. Trajkovic, Biomaterials, 2014, 35, 4428-4435.

31 S. P. Jovanović, Z. Syrgiannis, Z. M. Marković, A. Bonasera, D. P. Kepić, M. D. Budimir, D. D. Milivojević, V. D. Spasojević, M. D. Dramićanin, V. B. Pavlović and B. M. Todorović Marković, ACS Appl. Mater. Interfaces, 2015, 7, 25865-25874.

32 C. R. Ireson, L. R. Kelland, J. E. Rosenberg, R. M. Bambury, E. M. Van Allen, H. A. Drabkin, P. N. Lara, A. L. Harzstark, N. Wagle, R. A. Figlin, G. W. Smith, L. A. Garraway, T. Choueiri, F. Erlandsson, D. A. Laber, X. Wang, X. Sun, H. He, H. Yang, J. Lao, Y. Song, Y. Xia, H. Xu, X. Zhang and F. Huang, Mol. Cancer Ther., 2014, 3, 178-187.

33 A. Mewada, S. Pandey, M. Thakur, D. Jadhav and M. Sharon, J. Mater. Chem. B, 2014, 2, 698-705.

34 A.-M. Alam, B.-Y. Park, Z. K. Ghouri, M. Park and H.-Y. Kim, Green Chem., 2015, 17, 3791-3797.

35 J. Ge, M. Lan, B. Zhou, W. Liu, L. Guo, H. Wang, Q. Jia, G. Niu, X. Huang, H. Zhou, X. Meng, P. Wang, C.-S. Lee, W. Zhang and X. Han, Nat. Commun., 2014, 5, 4596.

36 T. Mosmann, J. Immunol. Methods, 1983, 65, 55-63.

37 Y. Dong, J. Shao, C. Chen, H. Li, R. Wang, Y. Chi, X. Lin and G. Chen, Carbon, 2012, 50, 4738-4743.

38 X. Li, S. Zhu, B. Xu, K. Ma, J. Zhang, B. Yang and W. Tian, Nanoscale, 2013, 5, 7776-7779.
39 S. Chen, J.-W. Liu, M.-L. Chen, X.-W. Chen and J.-H. Wang, Chem. Commun., 2012, 48, 7637-7639.

40 I. Matai, A. Sachdev and P. Gopinath, ACS Appl. Mater. Interfaces, 2015, 7, 11423-11435.

41 X. J. Mao, H. Z. Zheng, Y. J. Long, J. Du, J. Y. Hao, L. L. Wang and D. B. Zhou, Spectrochim. Acta, Part A, 2010, 75, 553-557.

42 H. Ding, S.-B. Yu, J.-S. Wei and H.-M. Xiong, ACS Nano, 2016, 10, 484-491.

43 G. Oza, K. Oza, S. Pandey, S. Shinde, A. Mewada, M. Thakur and M. Sharon, J. Fluoresc., 2015, 25, 9-14.

44 W. Kong, H. Wu, Z. Ye, R. Li, T. Xu and B. Zhang, J. Lumin., 2014, 148, 238-242.

45 Z. Bo, X. Shuai, S. Mao, H. Yang, J. Qian, J. Chen, J. Yan and K. Cen, Sci. Rep., 2014, 4, 4684.

46 S. Zhu, J. Zhang, S. Tang, C. Qiao, L. Wang, H. Wang, X. Liu, B. Li, Y. Li, W. Yu, X. Wang, H. Sun and B. Yang, Adv. Funct. Mater., 2012, 22, 4732-4740.

47 L. Bao, C. Liu, Z. L. Zhang and D. W. Pang, Adv. Mater., 2015, 27, 1663-1667.

48 R. K. Yadav, B. C. Nandy, S. Maity, S. Sarkar and S. Saha, Pharmacogn. Rev., 2015, 9, 73-80.

49 J. Heeg, U. Schubert and F. Kuchenmeister, Mikrochim. Acta, 2000, 133, 113-117.

50 C. Wu, C. Wang, T. Han, X. Zhou, S. Guo and J. Zhang, Adv. Healthcare Mater., 2013, 2, 1613-1619.

51 X. Yuan, Z. Liu, Z. Guo, Y. Ji, M. Jin and X. Wang, Nanoscale Res. Lett., 2014, 9, 108.

52 Y. Qin, Z.-W. Zhou, S.-T. Pan, Z.-X. He, X. Zhang, J.-X. Qiu, W. Duan, T. Yang and S.-F. Zhou, Toxicology, 2015, 327, 62-76.

53 D. Wang, L. Zhu, J.-F. Chen and L. Dai, Nanoscale, 2015, 7, 9894-9901.

54 K. Collins, T. Jacks and N. P. Pavletich, Proc. Natl. Acad. Sci. U. S. A., 1997, 94, 2776-2778.

55 J. Lukas, C. Lukas and J. Bartek, DNA Repair, 2004, 3, 9971007.

56 M. Havrdova, K. Hola, J. Skopalik, K. Tomankova, M. Petr, K. Cepe, K. Polakova, J. Tucek, A. B. Bourlinos and R. Zboril, Carbon, 2016, 99, 238-248.

57 G. Vincze, O. Szasz and A. Szasz, J. Biophys., 2015, 5, 97-114. 